\title{
SYNTHESIS AND CRYSTALLOGRAPHY OF A DIMERIZED CHALCONE DERIVATIVE
}

\author{
Sanjay Kumar', Vinutha V Salian², B. Narayana ${ }^{2}$, B. K. Sarojini ${ }^{3}$, \\ Sumati Anthal ${ }^{1}$ and Rajni Kant ${ }^{1 *}$ \\ ${ }^{1}$ X-ray Crystallography Laboratory, Department of Physics, University of Jammu, \\ Jammu Tawi-180006, India \\ ${ }^{2}$ Department of Studies in Chemistry, Mangalore University, Mangalagangothri-574 199, India. \\ ${ }^{3}$ Department of Industrial Chemistry, Mangalore University, Mangalagangothri-574 199, India. \\ *E-mail: rkant.ju@gmail.com
}

\begin{abstract}
The chalcone derivative, [3-(4-Chlorobenzoyl)-2,4-bis((4-propan-2-yl)phenyl)cyclobutyl](4-chlorophenyl)methan one $\left(\mathrm{C}_{36} \mathrm{H}_{34} \mathrm{Cl}_{2} \mathrm{O}_{2}\right)$, crystallizes in the monoclinic crystal system with space group $\mathrm{P} 2{ }_{1} / \mathrm{c}$ and unit cell parameters: $a=$ 18.4793(1) $\mathrm{A}, b=14.0239(7) \AA, c=11.8370(1) \AA, \beta=99.904(8)^{\circ}$ and $Z=4$. The crystal structure was solved using direct methods and refined by full matrix least squares procédures to a final R-factor of 0.0969 for 2319 observed reflections. In the crystal, $\mathrm{C}-\mathrm{H} \cdots \mathrm{O}$ contacts connect the molecule into a three-dimensional network. The molecule also contains two $\mathrm{C}-\mathrm{H} \cdots \mathrm{O}$ intramolecular interactions which stabilizes the crystal structure.

Keywords: Chalcone, Chlorobenzoyl, Direct methods, Crystallography, Intramolecular interactions.
\end{abstract}

(C) RASĀYAN. All rights reserved

\section{INTRODUCTION}

Chalcones comprise one of the most commonly occurring classes of medicinally important natural compounds as they possess various biological activities. ${ }^{1,2}$ Cyclobutane-containing natural products have, e.g., been reported for Combretum albopunctatum ${ }^{3}$ and Goniothalamus thwaitesii. ${ }^{4}$ Because of various biological activities of these natural compounds, the synthesis of cyclobutane-derived compounds is one of the most intensively studied photochemical reactions of chalcone derivatives. The nonlinear optical properties of the different chalcone derivatives have also been reported. ${ }^{5-8}$ These $\alpha, \beta$-unsaturated ketones possess a wide variety of biological activities, including anti-leishmanial ${ }^{9}$, anti-invasive ${ }^{10}$, antituberculosis $^{11}$, anti-fungal ${ }^{12}$, anti-malarial..$^{13,14}$

The crystal structures of some dimerized chalcones such as $r$-1,c-2,t-3,t-4- 1,3-bis(4-methoxyphenyl)-2,4bis(5-phenyl-1,3,4-oxadiazol-2-yl)cyclobutane 1,4-dioxane solvate ${ }^{15}$ and $r$-1,c-2,t-3,t-4-1,2-bis(4methoxyphenyl)-3,4-bis(5-phenyl-1,3,4-oxadiazol-2-yl) cyclobutane ${ }^{16}$ exist in the literature. In view of the pharmacological importance and potential of chalcone derivatives, the synthesis of such a compound was attempted and its molecular structure validated X-ray crystallographically.

\section{Synthesis}

\section{EXPERIMENTAL}

To a mixture of cuminaldehyde $(1.5 \mathrm{~mL}, 0.01 \mathrm{~mol})$ and 4-chloroacetophenone $(1.2 \mathrm{~mL}, 0.01 \mathrm{~mol})$ in ethanol $(50 \mathrm{~mL}), 15 \mathrm{~mL}$ of $10 \%$ sodium hydroxide solution was added and stirred at $0-5^{\circ} \mathrm{C}$ for 3 hours. The precipitate formed was collected by filtration and purified by recrystallization from ethanol. Single crystals suitable for X-ray diffraction study was grown by slow evaporation method and was dimerized during crystallization (M.P.: 467-469 K). The synthetic route for the preparation of the compounds is given in Scheme-1. 
RASĀYAN $J$. Chem.

Vol. 10 | No. 2 |522 - 527 | April - June | 2017<smiles>CC(=O)c1ccc(Cl)cc1</smiles><smiles>CC(C)c1ccc(/C=C/C(=O)c2ccc(Cl)cc2)cc1</smiles>

Dimerization<smiles>CC(C)c1ccc(C2C(C(=O)c3ccc(Cl)cc3)C(C(=O)c3ccc(Cl)cc3)C2c2ccc(C(C)C)cc2)cc1</smiles>

Scheme-1: Synthesis of [3-(4-Chlorobenzoyl)-2,4-bis((4-propan-2-yl)phenyl)cyclobutyl](4chlorophenyl)methanone.

\section{Crystal structure determination}

X-ray intensity data of the crystal of dimensions $0.30 * 0.20 * 0.20 \mathrm{~mm}^{3}$ having well defined morphology was collected on $X^{\prime}$ calibur CCD area-detector diffractometer equipped with graphite monochromated MoK $\alpha$ radiation $(\lambda=0.71073 \AA)$. The intensities were measured by employing $\omega$ scan mode for the diffraction angle ranging from 3.39 to $25^{\circ}$. X-ray intensity data of 10623 reflections were collected at 293(2) $\mathrm{K}$ and out of these reflections 5176 were found unique. 2319 reflections were treated as observed by employing the criterion $\mathrm{I}>2 \sigma$ (I). Data was corrected for Lorentz-polarization and absorption factors. The structure was solved by direct methods using SHELXS $97{ }^{17}$ and was refined using SHELXL97. ${ }^{17}$ All non-hydrogen atoms of the molecule were located in the best E-map. All the hydrogen atoms were geometrically fixed and allowed to ride on the corresponding carbon with $\mathrm{C}-\mathrm{H}=0.93-0.97 \AA$ and $\mathrm{U}_{\text {iso }}=1.2$ $\mathrm{U}_{\text {eq }}(\mathrm{C})$, except for the methyl groups where $\mathrm{U}_{\text {iso }}(\mathrm{H})=1.5 \mathrm{U}_{\text {eq }}(\mathrm{C})$. The final refinement cycles converged to an R-factor of $0.0969\left[w \mathrm{R}\left(\mathrm{F}^{2}\right)=0.1554\right]$ for 2319 observed reflections. A relatively large value of $\mathrm{R}$ factor could be due to poor quality crystallization of this material. Residual electron densities ranges from -0.239 to $0.229 \mathrm{e}^{-3}$. Geometrical calculations of the molecule were done using the WinGX ${ }^{18}$, PARST ${ }^{19}$ and PLATON ${ }^{20}$ software.

Crystallographic information has been deposited at the Cambridge Crystallographic Data Centre with CCDC number 1530154. This data can be accessed free of charge at Cambridge Crystallographic Data Centre via www.ccdc.cam.ac.uk/data_request/cif. The crystallographic and refinement data of the crystal is given in Table-1.

Table-1: Crystallographic characteristic, the $\mathrm{X}$-ray data collection and structure-refinement parameters for $\mathrm{C}_{36} \mathrm{H}_{34} \mathrm{Cl}_{2} \mathrm{O}_{2}$.

\begin{tabular}{c|c}
\hline CCDC Number & 1530154 \\
\hline System, Space group, $\mathrm{Z}$ & Monoclinic, $\mathrm{P} 2_{1} / \mathrm{c}, 4$ \\
\hline$a, b, c \AA$ & $18.4793(15), 14.0239(7), 11.8370(1)$ \\
\hline$\beta, \mathrm{deg}$ & $99.904(8)$ \\
\hline $\mathrm{V}, \AA^{3}$ & $3021.9(4)$ \\
\hline $\mathrm{D}_{\mathrm{x}}{\mathrm{g} . \mathrm{cm}^{-3}}^{-3}$ & 1.252 \\
\hline Radiation, $\lambda, \AA$ & 0.71073 \\
\hline$\mu, \mathrm{mm}^{-1}$ & 0.246 \\
\hline
\end{tabular}


RASĀYAN $J$. Chem.

Vol. 10 | No. 2 |522 - 527 | April - June | 2017

\begin{tabular}{c|c}
\hline $\mathrm{T}, \mathrm{K}$ & $293(2)$ \\
\hline Sample size, $\mathrm{mm}^{3}$ & $0.30 * 0.20 * 0.20$ \\
\hline Diffractometer & $X^{\prime}$ calibur Sapphire3 CCD area-detector \\
\hline Scan mode & multi-scan \\
\hline Absorption correction & $0.63965,1.00000$ \\
\hline $\mathrm{T}_{\min }, \mathrm{T}_{\max }$ & $3.39 \rightarrow 25$ \\
\hline$\theta$ range, deg & $10623 / 5176$ \\
\hline$h, k, l$ ranges & 2319 \\
\hline Reflections total/unique & 0.0681 \\
\hline Reflections observed $[\mathrm{I}>2 \sigma(\mathrm{I})]$ & 0.1338 \\
\hline $\mathrm{R}_{\text {int }}$ & 1200 \\
\hline $\mathrm{R}_{\text {sigma }}$ & 0.0969 \\
\hline $\mathrm{F}(000)$ & 0.1554 \\
\hline $\mathrm{R}$ & 0.00 \\
\hline$w \mathrm{R}\left(\mathrm{F}^{2}\right)$ & 366 \\
\hline$(\Delta / \sigma)_{\max }$ & 1.020 \\
\hline $\mathrm{S}$ & $0.229 /-0.239$ \\
\hline Number of refined parameters & SHELXS97, SHELXL97, PARST, PLATON, $14 \rightarrow 13$ \\
\hline$\Delta \rho_{\max } / \Delta \rho_{\min }, \mathrm{e} / \AA^{3}$ & ORTEP
\end{tabular}

\section{RESULTS AND DISCUSSION}

The molecular structureis shown in Figure-1(ORTEP). ${ }^{21}$ It comprises of dimerized chalcone derivative around a cyclobutane. The cyclobutane moiety bears one aromatic substituent on each carbon atom. The structural parameters, including bond distances and bond angles (Table-2) show normal geometry. ${ }^{22}$

Table-2: Selected bond distances and bond angles.

\begin{tabular}{|c|c|c|c|}
\hline \multicolumn{2}{|c|}{ Bond Distances $(\AA)$} & \multicolumn{2}{|c|}{ Bond Distances $(\AA)$} \\
\hline $\mathrm{C} 1-\mathrm{C} 2$ & 1.441(1) & C16-CL1 & $1.728(7)$ \\
\hline $\mathrm{C} 2-\mathrm{C} 3$ & $1.428(9)$ & C19-C20 & $1.505(6)$ \\
\hline $\mathrm{C} 2-\mathrm{C} 4$ & $1.531(8)$ & C19-C29 & $1.572(7)$ \\
\hline C7-C10 & $1.489(6)$ & $\mathrm{C} 23-\mathrm{C} 26$ & $1.527(9)$ \\
\hline C10-H10 & 0.9800 & $\mathrm{C} 26-\mathrm{C} 27$ & $1.307(1)$ \\
\hline C10-C11 & $1.566(7)$ & $\mathrm{C} 26-\mathrm{C} 28$ & $1.395(1)$ \\
\hline C10-C29 & $1.548(6)$ & C28-H28A & 0.9600 \\
\hline $\mathrm{C} 11-\mathrm{C} 12$ & $1.498(7)$ & C29-C30 & $1.498(6)$ \\
\hline C11-C19 & $1.523(6)$ & $\mathrm{C} 30-\mathrm{O} 2$ & $1.220(5)$ \\
\hline $\mathrm{C} 12-\mathrm{O} 1$ & $1.217(6)$ & C30-C31 & $1.484(7)$ \\
\hline C12-C13 & $1.482(7)$ & C34-CL2 & $1.724(6)$ \\
\hline \multicolumn{2}{|c|}{ Bond Angles $\left({ }^{\circ}\right)$} & \multicolumn{2}{|c|}{ Bond Angles $\left({ }^{\circ}\right)$} \\
\hline $\mathrm{C} 1-\mathrm{C} 2-\mathrm{C} 3$ & $113.2(8)$ & C19-C20-C21 & $122.9(5)$ \\
\hline $\mathrm{C} 3-\mathrm{C} 2-\mathrm{C} 4$ & $115.2(7)$ & C19-C29-C30 & $116.2(4)$ \\
\hline C6-C7-C10 & $120.8(5)$ & C20-C19-C29 & $120.2(4)$ \\
\hline C10-C11-C19 & $90.4(4)$ & $\mathrm{C} 23-\mathrm{C} 26-\mathrm{C} 27$ & $119.2(8)$ \\
\hline C10-C29-C19 & $89.3(4)$ & C27-C26-C28 & $124.5(8)$ \\
\hline C11-C19-C29 & $89.0(4)$ & C29-C10-C11 & $88.4(3)$ \\
\hline $\mathrm{C} 13-\mathrm{C} 12-\mathrm{O} 1$ & $120.1(6)$ & C29-C30-C31 & $118.3(5)$ \\
\hline C15-C16-CL1 & 119.2(7) & C33-C34-CL2 & $119.1(5)$ \\
\hline
\end{tabular}




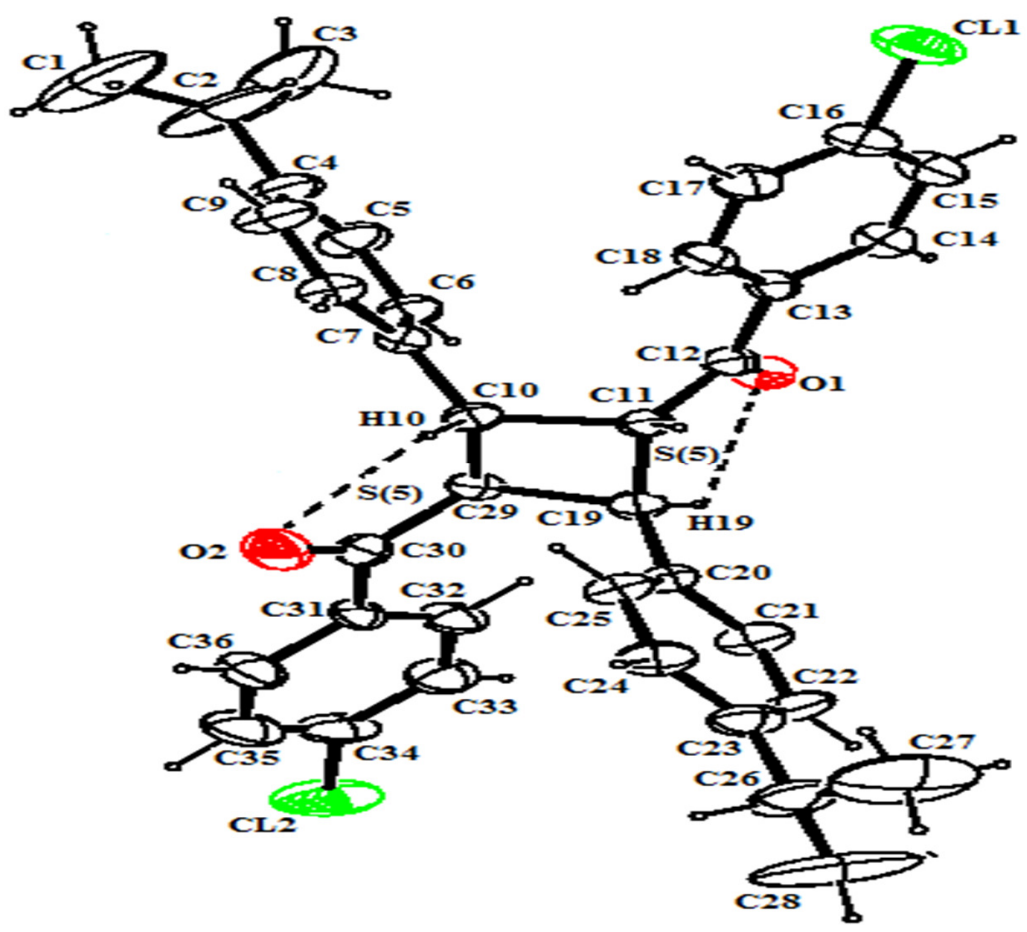

Fig.-1: ORTEP view of the molecule. Displacement ellipsoids are shown at the $40 \%$ probability level along with atomic labeling scheme. Hydrogen atoms are drawn at arbitrary radii and are not labeled for clarity. The graph-set motifs are also shown (dotted lines).

The length of the bonds $\mathrm{C} 10-\mathrm{C} 11, \mathrm{C} 10-\mathrm{C} 29$ and $\mathrm{C} 7-\mathrm{C} 10, \mathrm{C} 11-\mathrm{C} 12$ is similar to the corresponding distances as observed in case of some other tetra-aryl substituted cyclobutanes. ${ }^{23,24}$ The distances of the bonds opposite to each other in the cyclobutane have nearly the same value and the endocyclic bond angles being very close to $90^{\circ}$; thus assume the shape of a rectangle. The propan-2-yl group and the phenyl rings lying on both sides of cyclobutane are not coplanar [torsion angle being $\mathrm{C} 1-\mathrm{C} 2-\mathrm{C} 4-\mathrm{C} 5$ $\left(108.0(1)^{\circ}\right)$ and C24-C23-C26-C27 $\left(150.8(1)^{\circ}\right)$, respectively (Table-3)].

The two chlorobenzoyl rings (the dihedral angle between them being $3.22(2)^{\circ}$ ) and the two phenyl rings (the dihedral angle between them being $8.95(2)^{\circ}$ ) are close to being planar. The dihedral angle between cyclobutane and each phenyl ring is $81.23(2)^{\circ}$ and $75.87(2)^{\circ}$, respectively, while the dihedral angle between the cyclobutane ring and each of the chlorobenzoyl ring is $50.74(2)^{\circ}$ and $53.29(2)^{\circ}$, respectively. The $\mathrm{C} 11$ and $\mathrm{C} 19$ atoms of the cyclobutane are deviated significantly (deviations being $0.0893(5) \AA$ and $-0.0889(5) \AA$ respectively). The relative orientation of all the four aromatic substituents attached to central cyclobutane ring corresponds to cis-trans-cis-trans and this may be due to molecular centrosymmetry.

In the crystal structure, there exists $\mathrm{C} 10-\mathrm{H} 10 \ldots \mathrm{O} 2$ and $\mathrm{C} 19-\mathrm{H} 19 \ldots \mathrm{O} 1$ intramolecular interactions, both resulting in the formation of $\mathrm{S}(5)$ graph-set motifs. Only one intermolecular hydrogen bond C22$\mathrm{H} 22 \ldots \mathrm{O} 1$ is observed that links molecule into infinite chains along the $y$-direction (Figure-2). Details of intra/inter-molecular hydrogen bonds are given in Table-4.

Table-3: Selected torsion angles

\begin{tabular}{c|c|c|c}
\hline \multicolumn{2}{c|}{${\text { Torsion Angles }\left({ }^{\circ}\right)}^{2}$} & \multicolumn{2}{c}{ Torsion Angles $\left(^{\circ}\right)$} \\
\hline $\mathrm{C} 1-\mathrm{C} 2-\mathrm{C} 4-\mathrm{C} 5$ & $108.0(1)$ & C14-C15-C16-CL1 & $-179.6(5)$ \\
\hline $\mathrm{C} 1-\mathrm{C} 2-\mathrm{C} 4-\mathrm{C} 9$ & $-70.2(1)$ & $\mathrm{C} 18-\mathrm{C} 13-\mathrm{C} 12-\mathrm{O} 1$ & $-177.2(6)$ \\
\hline
\end{tabular}


RASĀYAN $J$. Chem.

Vol. 10 | No. 2 |522 - 527 | April - June | 2017

\begin{tabular}{c|c|c|c}
\hline $\mathrm{C} 6-\mathrm{C} 7-\mathrm{C} 10-\mathrm{C} 11$ & $119.5(6)$ & $\mathrm{C} 19-\mathrm{C} 11-\mathrm{C} 10-\mathrm{C} 29$ & $-13.1(4)$ \\
\hline $\mathrm{C} 7-\mathrm{C} 10-\mathrm{C} 11-\mathrm{C} 12$ & $-14.6(7)$ & $\mathrm{C} 19-\mathrm{C} 20-\mathrm{C} 25-\mathrm{C} 24$ & $175.8(6)$ \\
\hline $\mathrm{C} 7-\mathrm{C} 10-\mathrm{C} 29-\mathrm{C} 30$ & $132.9(5)$ & $\mathrm{C} 20-\mathrm{C} 19-\mathrm{C} 29-\mathrm{C} 30$ & $-21.2(7)$ \\
\hline $\mathrm{C} 8-\mathrm{C} 7-\mathrm{C} 10-\mathrm{C} 29$ & $39.7(8)$ & $\mathrm{C} 22-\mathrm{C} 23-\mathrm{C} 26-\mathrm{C} 28$ & $150.5(1)$ \\
\hline $\mathrm{C} 11-\mathrm{C} 12-\mathrm{C} 13-\mathrm{C} 14$ & $-176.0(5)$ & $\mathrm{C} 24-\mathrm{C} 23-\mathrm{C} 26-\mathrm{C} 27$ & $150.8(1)$ \\
\hline $\mathrm{C} 12-\mathrm{C} 11-\mathrm{C} 10-\mathrm{C} 29$ & $-134.7(5)$ & O2-C30-C31-C32 & $162.2(5)$ \\
\hline $\mathrm{C} 12-\mathrm{C} 11-\mathrm{C} 19-\mathrm{C} 20$ & $-99.3(6)$ & $\mathrm{C} 36-\mathrm{C} 35-\mathrm{C} 34-\mathrm{C} 22$ & $-179.3(5)$ \\
\hline
\end{tabular}

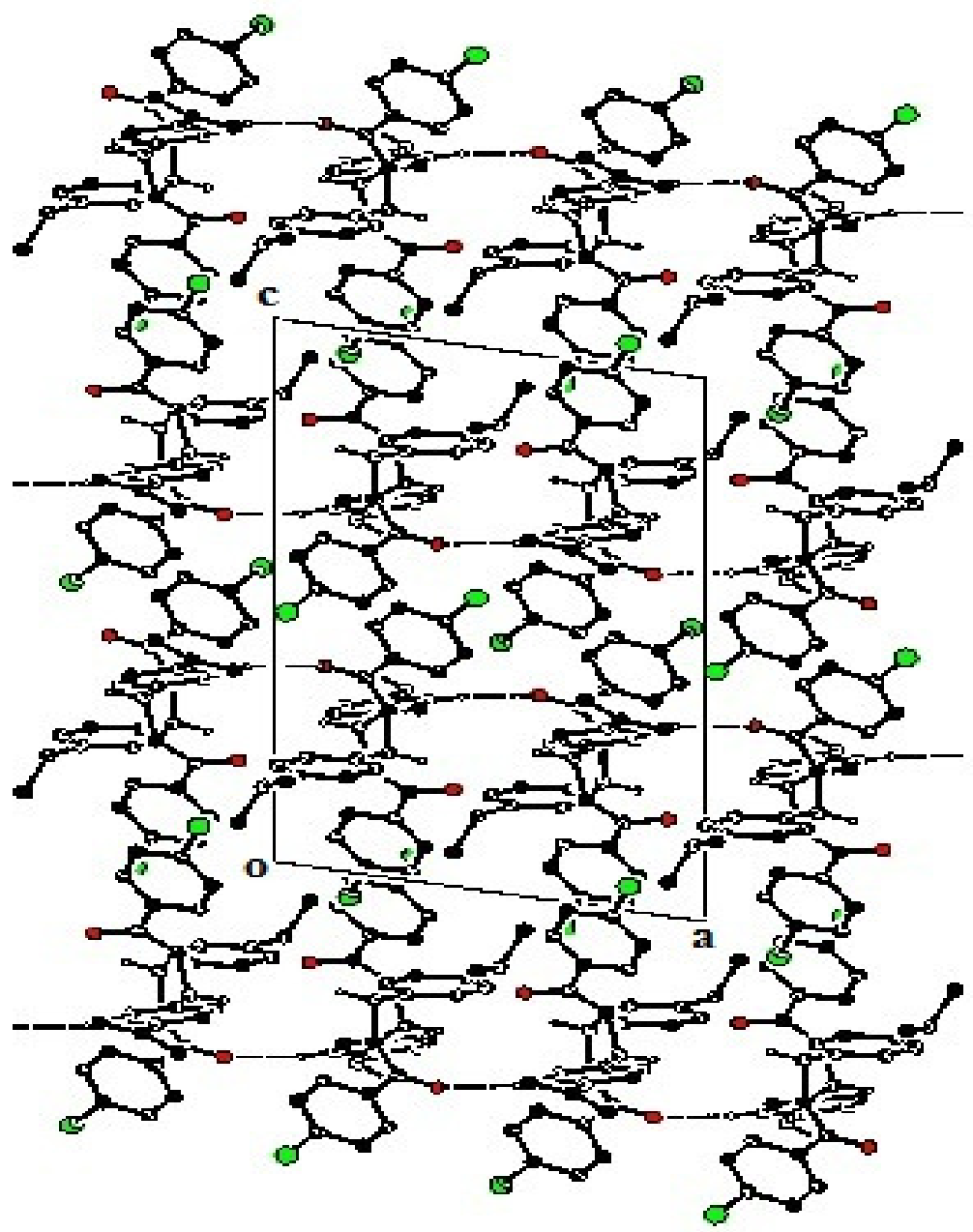

Fig.-2: Packing of the molecule along b-axis.

Table-4: Hydrogen bonding geometry (e.s.d.'s in parentheses)

\begin{tabular}{c|c|c|c|c}
\hline $\mathrm{D}-\mathrm{H} \ldots \mathrm{A}$ & $\mathrm{D}-\mathrm{H}(\AA)$ & $\mathrm{H} \ldots \mathrm{A}(\AA)$ & $\mathrm{D} \ldots \mathrm{A}(\AA)$ & $\mathrm{D}-\mathrm{H} \ldots \mathrm{A}\left({ }^{\circ}\right)$ \\
\hline $\mathrm{C} 10-\mathrm{H} 10 \ldots \mathrm{O} 2$ & 0.98 & 2.38 & $2.821(6)$ & 106 \\
\hline $\mathrm{C} 19-\mathrm{H} 19 \ldots \mathrm{O} 1$ & 0.98 & 2.44 & $2.833(7)$ & 103 \\
\hline $\mathrm{C} 22-\mathrm{H} 22 \ldots \mathrm{O} 1^{\mathrm{i}}$ & 0.93 & 2.53 & $3.203(7)$ & 130 \\
\hline
\end{tabular}

Symmetry code: (i) $x, 3 / 2-y, 1 / 2+z$

\section{ACKNOWLEDGMENT}

Rajni Kant is thankful to the Indian Council of Medical Research and the Department of Science and Technology, New Delhi for funding under sponsored research projects (No. BIC/12(14)/2012 and EMR/2014/000467). BN thanks UGC for financial assistance through BSR one time grant for the purchase of chemicals. VVS thanks Mangalore University for research facilities. 


\section{REFERENCES}

1. J. R. Dimmock, D. W. Elias, M. A. Beazely and N. M. Kandepu, Curr. Med. Chem., 6, 1125 (1999).

2. J. P. J. Marais, D. Ferreira and D. Slade, Phytochemistry, 66, 2145 (2005).

3. D. R. Katerere, A. I. Gray, A. R. Kennedy, R. J. Nash and R. D. Waigh, Phytochemistry, 65, 433 (2004).

4. V. Seidel, F. Bailleul and P. G. Waterman, Phytochemistry, 55, 439 (2000).

5. B. K. Sarojini, B. Narayana, B. V. Ashalatha, J. Indira and K. G. Lobo, J. Cryst. Grow., 295, 54 (2006).

6. P. Poornesh, S. Shettigar, G. Umesh, K. B. Manjunatha, K. P. Kamath, B. K. Sarojini and B. Narayana, Optical Materials, 31, 854 (2009).

7. J. Indira, P. P. Karat and B. K. Sarojini, J. Cryst. Growth, 242, 209(2002).

8. S. Shettigar, G. Umesh, K. Chadrasekharan, B. K. Sarojini and B. Narayana, Optical Materials, 30, 1297 (2008).

9. S. F. Nielsen, S. B. Christensen, G. Cruciani, A. Kharazmi and T. Liljefors, $J$. Med. Chem., 41, 4819 (1998).

10. S. Mukherjee, V. Kumar, A. K. Prasad, H. G. Raj, M. E. Bracke, C. E. Olsen, S. C. Jain and V. S. Parmar, Bioorg. Med. Chem., 9, 337 (2001).

11. Y. M. Lin, Y. Zhou, M. T. Flavin, L. M. Zhou, W. Nie and F. C. Chen, Bioorg. Med. Chem., 10, 2795 (2002).

12. S. N. Lopez, M. V. Castelli, S. A. Zacchino, J. N. Dominguez, G. Lobo, C. C. Jaime, J. C. G. Cortes, J. C. Ribas, C. Devia, M. R. Ana and D. E. Ricardo, Bioorg. Med. Chem., 9, 1999 (2001).

13. A. Agarwal, K. Srivastava, S. K. Puri and P. M. S. Chauhan, Bioorg. Med. Chem., 13, 4645 (2005).

14. S. Kumar, A. Jayashree, B. Narayana, B. K. Sarojini, L. Kótai, S. Anthal and R. Kant, Eur. Chem. Bull., 5, 501 (2016).

15. Y. Zheng, J. P. Zhuang, W. Q. Zhang, X. B. Leng and L. H. Weng, Acta Cryst., E57, o1029 (2001).

16. J. P. Zhuang and Y. Zheng, Acta Cryst., E58, o1195 (2002).

17. G. M. Sheldrick, University of Gottingen, Germany, (1997).

18. L. J. Farrugia, Journal of Applied Crystallography, 32, 837 (1999).

19. M. Nardelli, Journal of Applied Crystallography, 28, 659 (1995).

20. A. L. Spek, Acta. Crystallographica, D65, 148(2009).

21. L. J. Farrugia, Journal of Applied Crystallography, 30, 565 (1997).

22. F. H. Allen, O. Kennard, D. G. Watson, L. Brammer, A. G. OrpenandR. Taylor, Journal of the Chemical Society Perkin Transactions, 2, S1 (1987).

23. P.S.Nayak, B.Narayana, H.S.Yathirajan, T.Gerber, E.Hosten and R.Betz, Acta Cryst., E68, o3272 (2012).

24. S. Zhang and J. Zhuang, Acta Cryst., E70, o311 (2014).

[RJC-1607/2017] 